\title{
Riding the Wave of Credit: Are Longer Expansions Really a Bad Omen?
}

\section{Vítor Castro ${ }^{1,2}$ (D) Rodrigo Martins ${ }^{3,4}$}

Published online: 4 December 2019

(C) The Author(s) 2019

\begin{abstract}
Some studies argue that credit booms that end up in banking crises are usually longer than those that end without creating havoc. However, they do not test this hypothesis empirically. This paper employs a duration model to assess the relationship between the length of credit booms and their outcome. The empirical analysis shows that credit expansions that end in banking crisis are indeed more prone to last longer than those that end softly. Furthermore, differences in length patterns are found to start in the build-up phase, extending to the unwinding phase of credit cycles.
\end{abstract}

Keywords Credit booms $\cdot$ Duration analysis $\cdot$ Banking crisis

JEL Classification C41 · E51

\section{Introduction}

The growing importance of credit in the day to day economic activity of individuals, firms and governments has been a clear trend in recent decades. Today, credit is everywhere and stands as an essential tool to promote investment and economic

Vítor Castro

v.m.q.castro@lboro.ac.uk

Rodrigo Martins

rodrigom@fe.uc.pt

1 School of Business and Economics, Loughborough University, Loughborough, Leicestershire LE11 3TU, UK

2 Economic Policies Research Unit (NIPE), University of Minho, Campus of Gualtar, 4710-057 Braga, Portugal

3 Faculty of Economics, University of Coimbra, Av. Dias da Silva 165, 3004-512 Coimbra, Portugal

4 Centre for Business and Economics Research (CeBER), Av. Dias da Silva 165, 3004-512 Coimbra, Portugal 
prosperity. However, history has taught us that this apparent virtuous cycle eventually comes to an end with unforeseen consequences to the economy. It is a dangerous gamble as showed by the recent global financial triggered, in part, by a swift increase of mortgage loans in the United States. Some credit booms are indeed followed by moments of intense financial distress banking and economic crises (Jordà et al. 2011; Schularick and Taylor 2012; Boissay et al. 2016; Jordà et al. 2016). Our data reports this to be the case for one out of four credit expansions identified from 1975 to 2016. The significant number of disaster events contributed decisively to the belief that credit booms need to be monitored and better understood.

One fundamental question regarding credit expansions is how to anticipate their benign or malignant nature, and researchers have tried to identify differences between them but with limited success. All in all, the most consistent conclusion found in the literature is that harmful credit booms (or bad credit booms) tend to exhibit larger magnitudes and longer durations. Barajas et al. (2009) found that around $40 \%$ of credit expansions lasting between 9 and 12 years end up in a crisis and for those over 13 years this is a virtual certainty. When analyzing the length of credit booms, Arena et al. (2015) report that approximately half of those that end in a banking crisis last for over six years while only $25 \%$ of benign booms last this long. The conclusion that longer expansions have a higher probability of being associated with a banking crisis is reported by several studies (see Gourinchas et al. 2001; Castro and Kubota 2013; Dell'Ariccia et al. 2016; Meng and Gonzalez 2017). However, as far as we are concerned, only Castro and Kubota (2013) use adequate statistical methods as an attempt to address this issue. Relying on a continuous-time Weibull duration model, they provide evidence of positive duration dependence in credit booms, in general, and in those that end badly, in particular.

This paper contributes to the literature on credit booms in various directions and goes beyond Castro and Kubota's (2013) work in several ways. First, we employ a discrete-time duration model that allows for the inclusion of (time-varying) economic explanatory variables. This provides a more complete control of the economic environment. Second, we use a different set of criteria to define episodes of credit booms (different thresholds and detrending techniques). Third, regarding bad credit booms, Castro and Kubota (2013) only show the presence of duration dependence in their dynamics; in this study we move a step forward and compare bad with good credit booms dynamics. This approach makes it possible to provide the (lacking) statistical evidence that bad credit booms tend to last longer than good ones. Fourth, we extend the duration analyses to the build-up and unwinding phases of the credit cycle, assessing whether they are fundamentally alike or not. This particular analysis also allows us to identify whether different patterns emerge when credit cycles are split into those that generate harmful outcomes and those that do not. Finally, we rely on a more extensive quarterly dataset covering 67 countries from 1975q1 to 2016q4.

The empirical analysis provides strong evidence that harmful credit expansions are indeed more prone to last longer than those that land softly. It also shows that their build-up and unwinding phases differ, thus generating distinct credit cycles. This study concludes that duration can be used as an early warning instrument to evaluate the benign or malignant nature of credit booms.

The rest of the paper is organized as follows. Section 2 surveys the literature while Section 3 presents the econometric model. Section 4 describes the data and methodology. The empirical results are presented and discussed in Section 5. Finally, Section 6 concludes. 


\subsection{Literature Review}

The investigation on credit booms has been conducted mainly through data analysis and the literature has highlighted the association between credit expansions and macroeconomic dynamics. Rises in capital inflows, productivity shocks and general improvements in the economy, allied to excessive optimism, are found to explain the build-up of such events (see, for instance, Mendoza and Terrones 2008, 2012; Dell'Ariccia et al. 2016; Amri et al. 2016; Avdjiev et al. 2018; Castro and Martins 2019). Additionally, financial reforms associated with financial liberalization and domestic differences such as expansionary monetary and fiscal policies, less flexible exchange rate regimes, debt composition and weak supervision of the banking system are also associated with periods of abnormal credit growth (Elekdag and Wu 2013; Arena et al. 2015; Dell'Ariccia et al. 2016; Avdjiev et al. 2018).

Estimating a fixed effects logit model over a panel of developed and developing countries, Castro and Martins (2019) show that credit booms depend not only on the quantity of credit but are also influenced by its relative price. Likewise, economic growth and economic openness also build-up the conditions for the appearance of lending booms. They also report that economies that can generate more liquidity are less likely to be affected by credit booms.

Banking crisis are often associated with excessive credit expansions. The circumstances in which this happens has been an important topic of research. Dell'Ariccia et al. (2016) point out that a higher level of financial depth increases the probability of a boom ending badly. Arena et al. (2015) found that when credit booms end in banking crisis, macroeconomic fluctuations seem to be larger and exhibit more sudden declines. According to Meng and Gonzalez (2017), this is also the case when the dimension of the financial sector grows, particularly above macroeconomic consistent levels. Yet, they report no association between bad booms and macroeconomic and financial policies - exception made to the quality of regulations and supervision of the banking system.

In a recent work, Castro and Martins (2018) found that credit booms that are driven by high levels of capital inflows and/or by increases in the ratio of credit to deposits and those that are generally supported by lower interest rates tend to have an increased likelihood of ending up in a full blown banking crisis. However, the opposite seems to happen when right wing parties are in office. The authors also report that, bad credit expansions are less likely to occur under the watch of more independent Central Banks. However, the literature has struggled to find consistent differences between good and bad credit expansions. Some papers - like, for example, Gourinchas et al. (2001) - actually report no relevant changes in key macroeconomic variables between them. Overall, the difficulty in finding consistent predictors that can support or extend theoretical models has restricted the ability for empirical studies to present more credible policy recommendations.

Nevertheless, most studies seem to agree that credit booms gone badly are associated with larger magnitudes and longer durations, but to reach this conclusion most of them rely on comparative descriptive statistics and graphical analysis. The exceptions are Meng and Gonzales (2017) and Castro and Kubota (2013). The former collapse their panel data into a cross-section and estimate probit models where the dependent variable takes value of 1 if a credit boom episode is followed within two years by a banking crisis (and 0 otherwise) and add to the regressors a variable measuring the length of each boom. The later uses a continuous-time Weibull duration model to confirm the length nexus of credit booms. None 
of them provides a comparative analysis between the duration dynamics of bad and good credit booms. This paper embraces that endeavour and confirms statistically the existence of differences in the duration pattern of good and bad lending expansions.

\subsection{Econometric Model}

For the duration analysis developed in this study, we rely on Prentice and Gloeckler's (1978) discrete-time version of the proportional hazards duration model, ${ }^{1}$ with the respective discrete-time hazard function given $b y^{2}$ :

$$
\begin{aligned}
P_{i t}=\operatorname{Pr}\left[T_{i}\right. & \left.=t \mid T_{i} \geq t, \mathbf{x}_{i t}\right]=1-e^{-h_{t} e^{\beta^{\prime} \mathbf{x}_{i t}}}=1-e^{-e^{\lambda_{t}+\beta^{\prime} \mathbf{x}_{i t}}} \\
& \Leftrightarrow \ln \left[-\ln \left(1-P_{i t}\right)\right]=\lambda_{t}+\boldsymbol{\beta}^{\prime} \mathbf{x}_{i t}
\end{aligned}
$$

where $T$ is the duration variable and $t$ denotes the moment in time when the value of each independent variable is observed. Given that time is discrete, $t$ corresponds to the amount of time (measured in quarters) during which the event has been "running" or has been "active", i.e. the amount of time since the beginning of the event or the time span. ${ }^{3}$ This model is equivalent to the complementary log-log (or cloglog) function, where $\lambda_{t}\left(=\ln h_{t}\right)$ represents the logarithm of an unspecified (baseline hazard) function of time; $\mathbf{x}_{i t}$ is a vector of time-varying regressors. One suitable and quite popular specification for $\lambda_{t}$ is the discrete-time analogue to the continuous-time Weibull model, which yields:

$$
\lambda_{t}=\ln h_{t}=\alpha+(p-1) \ln t
$$

where $p$ parameterizes the duration dependence parameter. ${ }^{4}$ If $p>1(p<1)$, the conditional probability of a turning point occurring increases (decreases) as the phase gets older, i.e. there is positive (negative) duration dependence; if $p=1$ there is no duration dependence. Therefore, by estimating $p$, we can test for duration dependence in credit boom phases.

Prentice and Gloeckler (1978) and Allison (1982) show that the discrete-time loglikelihood function for a sample of $i=1, \ldots, n$ spells/booms can be written as follows:

$$
\ln L=\sum_{i=1}^{n} \sum_{j=1}^{t_{i}} y_{i t} \ln \left(\frac{P_{i j}}{1-P_{i j}}\right)+\sum_{i=1}^{n} \sum_{j=1}^{t_{i}} \ln \left(1-P_{i j}\right),
$$

\footnotetext{
${ }^{1}$ Although the time spell of credit booms is a continuous-time process, the available data are discrete (quarters). In addition, the potential conditioning factors of their duration vary over time. Hence, discretetime duration methods are more suitable for this study than continuous-time ones. For examples of empirical applications in Economics see Castro (2010), Agnello et al. (2013), Castro and Martins (2013) and Agnello et al. $(2015,2018)$.

2 The hazard function measures the rate at which credit boom spells end at time $t$, given that they lasted until that moment. In other words, it measures the probability of exiting from a boom state in moment $t$ conditional on the length of time in that state. This function helps to characterise the path of duration dependence.

${ }^{3}$ Countries do not experience a credit boom at the same time: sometimes, there is partial overlapping; other times, no overlapping occurs. Hence, we have different starting points for the events/spans across countries.

${ }^{4}$ In the continuous-time Weibull duration model the baseline hazard is $h_{t}=\gamma p t^{p-1}$, where $p>0, \gamma>0$ and $\gamma$ is a constant (for details, see Castro 2010). Hence, $\lambda_{t}=\ln h_{t}=\ln \left(\gamma p t^{p-1}\right)=\alpha+(p-1) \ln t$, with $\alpha=\ln (\gamma p)$ and $t=$ DurCreditBoom.
} 
where the dummy variable $y_{i t}$ is equal to 1 if credit boom $i$ in a given country ends at time $t$, and 0 otherwise. We estimate this model by Maximum Likelihood, substituting $P_{i j}$ by (1) and $\lambda_{t}$ by (2). This implies that the discrete-time log-likelihood function will be conditional on both time and the conditions observed for the different control variables at time $t$.

\section{Data and methodology}

To proceed with the duration analysis, we collected quarterly data for 67 countries from $1975 q 1$ to $2016 q 4$ on real credit. ${ }^{5}$ We use quarterly information on credit because it is more appropriate to assess cyclical movements and volatility associated with crisis episodes. The measure of credit considered is the deposit money bank claims on the private sector taken from the line $22 \mathrm{~d}$ of the IMF's International Financial Statistics (IFS). The amount of credit is expressed in real terms by dividing the nominal credit by the CPI index.

The next step is to identify credit booms to compute the respective duration. Following Castro and Martins (2019), we use the criteria developed by Gourinchas, et al. (2001) - and later updated by Barajas et al. (2009) - to identify credit booms. ${ }^{6}$ This method identifies a credit boom by looking at the growth of credit in the economy, proxied by the bank credit to the private sector as a percentage of GDP, $L / y$. Thus, Gourinchas et al. (2001) define a credit boom as an episode where the deviation of the ratio $L / y$ from a country-specific trend in country $i$ at period $t$ (with the trend being calculated up to that period $t$ ) exceeds a determined threshold. In particular, we define that a credit boom takes place if the ratio of private credit to GDP meets the following condition: the deviation of $L / y$ from its estimated trend is greater than 1.5 times its standard deviation or the year-on-year growth rate of $L / y$ exceeds $20 \%$. The HP-filter is used to compute the trend, where the value of Lagrange Multiplier employed in the maximization problem is $\lambda=1600$ (for quarterly data). By organizing the data into spells of credit we can compute their duration, i.e. the number of quarters in which a country is experiencing a credit boom (DurCreditBoom). For comparative purposes, we also consider other more restrictive thresholds: 1.75 and 2.0.

Table 1 presents some descriptive statistics for the number of episodes identified with this method (Obs.), their mean duration (Mean), standard deviation (S.D.), minimum (Min.) and maximum (Max.), accounting for different thresholds: 1.5, 1.75 and 2.0. OECD and Non-OECD countries and different periods of time are also considered in this analysis. Simultaneously, we distinguish between credit booms that end up in a systemic banking crisis from those that benefit from a soft landing. Like Barajas et al. (2009), we define the first episodes as bad credit booms and the others as good credit booms.

Based on the identification strategy of Barajas et al. (2009), we consider bad booms as credit booms that are followed by a systemic banking crisis either immediately or within eight quarters of their final period. Episodes of systemic banking crises are obtained from Laeven and Valencia $(2008,2010,2012)$, extrapolated to quarterly data and updated for the more recent years following their procedure. ${ }^{7}$

\footnotetext{
${ }^{5}$ For the list of countries see footnotes in Table 1.

${ }^{6}$ Following Barajas et al. (2009) we also distinguish between bad and good credit booms. For other procedures see, for example, Mendoza and Terrones (2008, 2012) and Dell'Ariccia et al. (2016).

${ }^{7}$ These authors consider that a country experiences a systemic banking crisis if its banking system faces significant signs of financial stress (indicated by significant bank runs, losses, and bank liquidations) and moreover, if we observe significant policy interventions in response to the losses in the banking system.
} 
Table 1 Descriptive statistics for the episodes and duration of credit booms

\begin{tabular}{|c|c|c|c|c|c|}
\hline & \#Spells & Mean & Std.Dev. & Min. & Max. \\
\hline \multicolumn{6}{|l|}{ Threshold: 1.5} \\
\hline All countries & 220 & 8.04 & 5.82 & 1 & 32 \\
\hline OECD countries & 76 & 8.28 & 5.31 & 1 & 27 \\
\hline Non-OECD countries & 144 & 7.91 & 6.08 & 1 & 32 \\
\hline \multicolumn{6}{|l|}{ Decades: } \\
\hline $1975-1979$ & 8 & 4.63 & 2.20 & 2 & 9 \\
\hline 1980-1989 & 30 & 6.17 & 3.27 & 2 & 16 \\
\hline 1990-1999 & 59 & 9.18 & 5.64 & 2 & 27 \\
\hline $2000-2009$ & 48 & 9.33 & 6.46 & 2 & 32 \\
\hline 2010-2016 & 28 & 3.25 & 1.96 & 1 & 9 \\
\hline bad credit booms & 55 & 10.62 & 6.74 & 2 & 32 \\
\hline good credit booms & 165 & 7.18 & 5.22 & 1 & 32 \\
\hline \multicolumn{6}{|l|}{ Threshold: 1.75} \\
\hline All countries & 199 & 8.26 & 6.00 & 1 & 32 \\
\hline OECD countries & 64 & 8.73 & 5.60 & 1 & 27 \\
\hline Non-OECD countries & 135 & 8.04 & 6.19 & 1 & 32 \\
\hline \multicolumn{6}{|l|}{ Decades: } \\
\hline 1975-1979 & 7 & 5.00 & 2.08 & 3 & 9 \\
\hline $1980-1989$ & 27 & 6.30 & 3.39 & 2 & 16 \\
\hline 1990-1999 & 54 & 9.35 & 5.78 & 2 & 27 \\
\hline 2000-2009 & 43 & 9.70 & 6.74 & 2 & 32 \\
\hline 2010-2016 & 25 & 3.04 & 2.07 & 1 & 9 \\
\hline bad credit booms & 50 & 11.08 & 6.91 & 2 & 32 \\
\hline good credit booms & 149 & 7.32 & 5.36 & 1 & 31 \\
\hline \multicolumn{6}{|l|}{ Threshold: 2.0} \\
\hline All countries & 176 & 8.66 & 6.19 & 1 & 32 \\
\hline OECD countries & 59 & 8.76 & 5.78 & 2 & 27 \\
\hline Non-OECD countries & 117 & 8.61 & 6.41 & 1 & 32 \\
\hline \multicolumn{6}{|l|}{ Decades: } \\
\hline 1975-1979 & 7 & 5.00 & 2.08 & 3 & 9 \\
\hline 1980-1989 & 24 & 6.42 & 3.54 & 2 & 16 \\
\hline 1990-1999 & 49 & 9.80 & 5.85 & 2 & 27 \\
\hline $2000-2009$ & 41 & 9.56 & 6.95 & 2 & 32 \\
\hline 2010-2016 & 16 & 2.50 & 1.46 & 1 & 5 \\
\hline bad credit booms & 49 & 11.20 & 6.93 & 2 & 32 \\
\hline good credit booms & 127 & 7.68 & 5.60 & 1 & 31 \\
\hline
\end{tabular}

This table reports the number of episodes/spells (\#Spells), the mean duration (Mean), the standard deviation (St.Dev.), the minimum (Min.) and the maximum (Max.) duration for credit booms. The data are quarterly and comprises 67 countries over the period 1975q1-2016q4. Credit booms are identified using the works of Gourinchas et al. (2001) and Barajas et al. (2009). According to their criteria, we consider that a credit boom takes place when the deviation of the ratio of credit to GDP from its trend exceeds 1.5 times of its standard deviation or the (year-on-year) growth in the credit-GDP ratio exceeds $20 \%$. For robustness, we also allow for two more restrictive thresholds: 1.75 and 2.0

List of Countries: Argentina, Armenia, Australia, Austria, Belgium, Bolivia, Brazil, Bulgaria, Canada, Chile, Colombia, Costa Rica, Croatia, Cyprus, Czech Republic, Denmark, Dominican Republic, Ecuador, El Salvador, Estonia, Finland, France, Germany, Greece, Hungary, Iceland, India, Indonesia, Ireland, Israel, Italy, Japan, Kenya, Korea Republic, Latvia, Lithuania, Luxembourg, Malaysia, Malta, Mexico, Morocco, Netherlands, New Zealand, Norway, Panama, Paraguay, Peru, Philippines, Poland, Portugal, Romania, Russia, Slovak Republic, Slovenia, South Africa, Spain, Sri Lanka, Sweden, Switzerland, Taiwan, Thailand, Turkey, Ukraine, United Kingdom, United States, Uruguay, Venezuela 
Depending on how restrictive the threshold is, we can identify between 176 and 220 credit boom episodes over our entire sample period. Around two-thirds of the episodes took place in developing or emerging economies and, over time, most of the episodes of lending booms occur in the 1990s. On average, credit booms last around eight quarters but they are longer in the 1990s and 2000s (around 9 quarters). However, their mean duration is very similar when we compare the OECD with the Non-OECD countries.

From Table 1 we can also infer that not all lending booms end up in a crisis. In fact, only approximately 1 out of every 4 credit booms coincides or is followed by systemic banking crises. Another interesting feature is that, on average, those booms last more (11 quarters) than those that end up in a soft landing (around 7 quarters).

Barajas et al. (2009), Dell'Ariccia et al. (2016) and Meng and Gonzalez (2017), among others, notice that bad credit booms are larger and usually last longer than good credit booms. A visual analyses of the histograms reporting the duration of all, bad and good credit booms presented in Fig. 1, seems to confirm this idea: a higher proportion of good booms lasts less than two years while a substantial fraction of bad ones still lasts more than two years (the sample average of all credit booms). However, we do not know whether this difference is statistically relevant or not. This is an important issue that this study intends to address using a proper duration model.

As credit booms have been consistently associated with sharp increases in capital inflows that consequently raise the supply of loanable funds (Calderón and Kubota 2012; Gourinchas and Obstfeld 2012) and ultimately led to financial crises, ${ }^{8}$ the growth rate of foreign direct investment $(F D I g r)$ is used as proxy for this inflow of capital in our duration model. We expect them to be positively associated with the duration of credit booms. A better economic environment can also promote the build-up credit booms (Mendoza and Terrones 2008, 2012; Baron and Xiong 2017; Meng and Gonzales, 2017) and in that sense make them longer. To account for this effect, the growth rate of real GDP (GDPgr) is also added to the model. Moreover, the duration of credit booms might also be driven by external accounts. Meng and Gonzales (2017) show that an improved current account balance favours the occurrence of credit booms. However, this does imply that they will be longer. A positive stance may mean more cash or deposits available and less need for further credit. So, credit booms might be shorter when the current account balance improves. This effect is accounted for by adding the current account balance as percentage of GDP (CA_GDP) to the model. ${ }^{9}$

\section{Empirical analysis}

The findings of this study are discussed in this section. We start by presenting the main results on the time dynamics of bad and good credit booms; these are followed by a sensitivity analysis. Then we dig deeper into the build-up and unwinding phases of credit booms.

\footnotetext{
${ }^{8}$ See Jordà et al. (2011), Schularick and Taylor (2012), Boissay et al. (2016) and Jordà et al. (2016).

${ }^{9}$ Data for foreign direct investment are obtained from IMF's Balance of Payments Statistics; Datastream and national sources are used for real GDP series (in local currency); Current account as percentage of GDP is obtained from the World Development Indicators.
} 


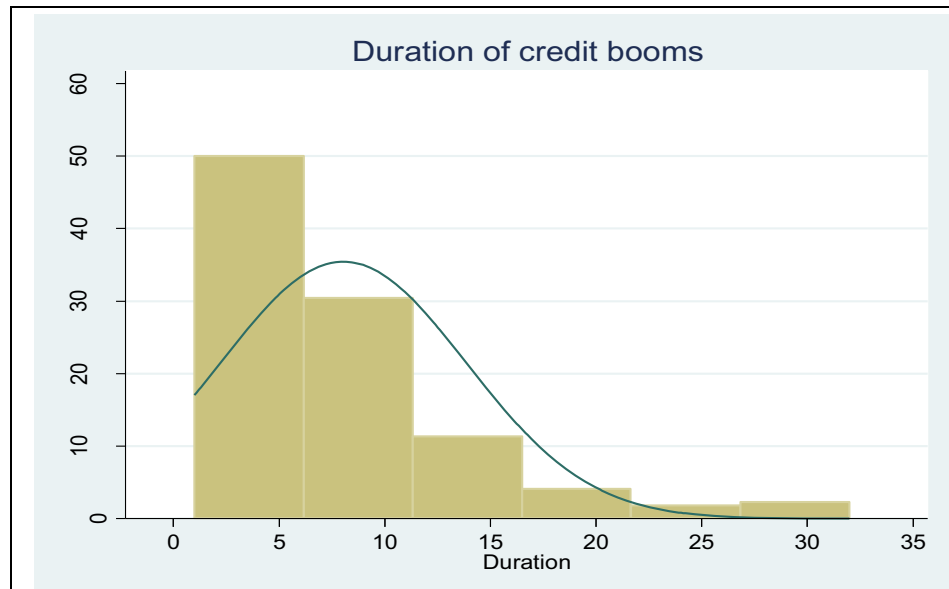

\#Spells=220; Mean=8.0; Std.Dev. $=5.8$

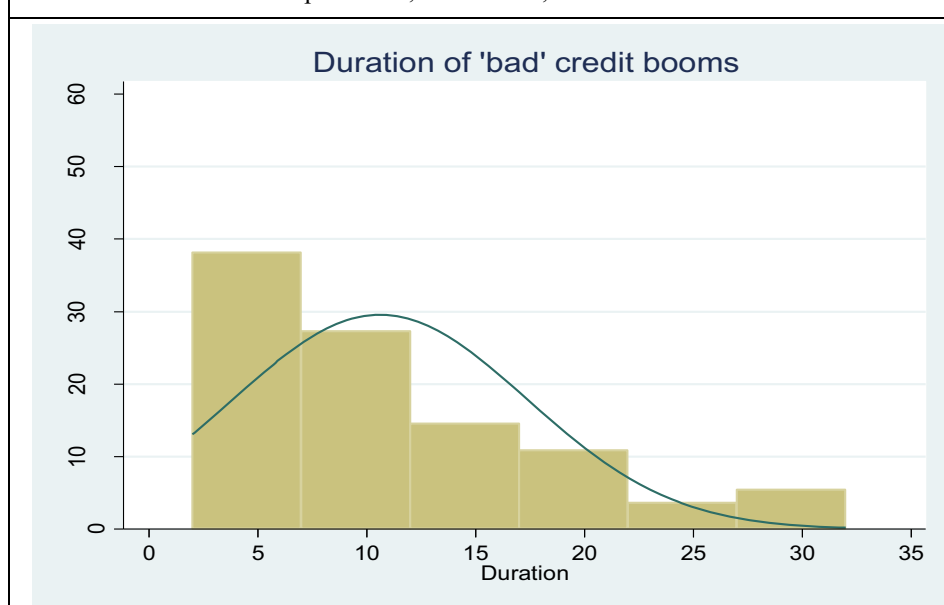

\#Spells=55; Mean=10.6; Std.Dev. $=6.7$

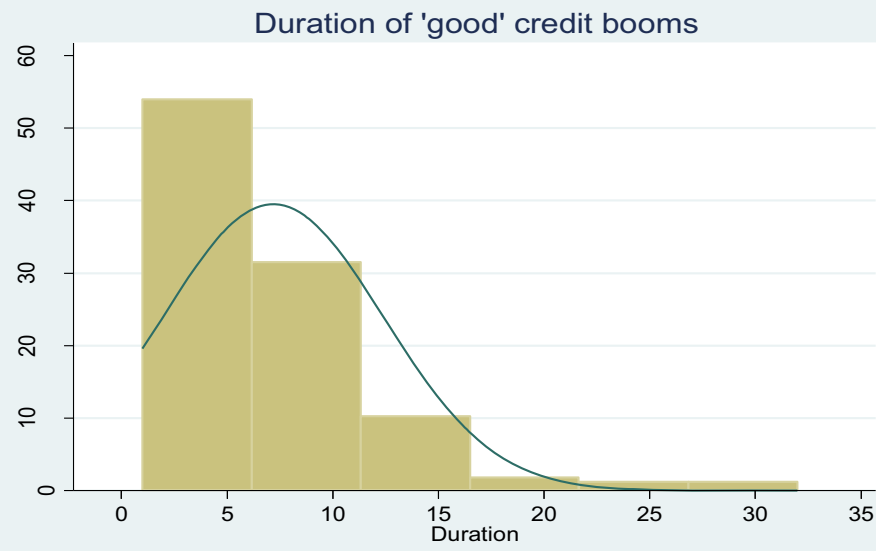

\#Spells=165; Mean=7.2; Std.Dev. $=5.2$

Fig. 1 Duration of credit booms 


\subsection{Main results}

The main empirical results from the estimation of the discrete-time duration model are summarised in Table 2. In this case, credit booms are identified using Gourinchas et al. (2001) and Barajas et al. (2009) criteria with a 1.5 threshold. The estimate of $p$ measures the magnitude of the duration dependence and a one-sided test is used to detect the presence of positive duration dependence, i.e. whether $p>1$ or not; the sign ' + ' indicates significance at a $5 \%$ level.

The results provide strong evidence of positive duration dependence for credit booms. This means that the likelihood of a credit boom ending increases as the time goes by, i.e. with its "age". Hence, "older" credit booms are at a higher risk of ending than "younger" ones. Taking for example the estimate of $p$ in regression 4 , we observe that a $1 \%$ increase in time (i.e. the length of the boom or its "age") is associated with a $2 \%$ increase in the hazard of a credit boom ending. ${ }^{10}$ Moreover, when the economic controllers are included, $p$ has proven to be statistically equal to 2 . This means that the second-order derivative of the baseline hazard function indicates the presence of constant positive duration dependence. Putting it differently, the probability of a credit boom ending at time $t$, given that it lasted until that period ("age"), increases over time at a constant rate. ${ }^{11}$

We start by estimating a very basic specification without accounting for any regressors, fixed or time effects (column 1). Then to account for countries heterogeneity, a dummy that takes the value of 1 for OECD countries, and 0 for the others, is added $(O E C D) .{ }^{12}$ However, no significant difference is detected in the mean duration of credit booms between OECD and Non-OECD countries. Decade-dummies are also added to control for time-effects, one for each decade (Dec70, Dec80, Dec90, Dec00, Dec10; Dec70 is the base-category). ${ }^{13}$ The results show that credit booms were, on average, more prone to last longer in the 1990s and 2000s but they have become shorter in more recent years.

Regression 3 accounts for important economic controllers in the credit booms; dynamics: foreign direct investment growth $(F D I g r)$, output growth $(G D P g r)$, and current account balance as percentage of GDP. These variables are lagged one period to avoid simultaneity problems.

The expansion of FDI inflows has proven to be positively associated with the likelihood of a credit boom ending over time, i.e. it is associated with shorter credit booms. This is in line with Calderon and Kubota's (2012) finding that FDI inflows are negatively related to the likelihood of credit booms. Hence, these capital inflows may indeed contribute to shorter booms because these flows might be initially supported by foreign credit, increasing the country's liquidity

\footnotetext{
${ }^{10}$ For further details on the interpretation of the duration dependence parameter, see Allison (2014).

${ }^{11}$ For details on the second-order derivative see Castro (2010).

${ }^{12}$ Initially, we tested for the presence of random and country-specific effects but the tests showed that none of these effects were statistically significant. Those results are available upon request. In fact, Claessens et al. (2012) note that with a limited number of observations/spells per country fixed effects may have to be ruled out. Hence, to allow for any eventual heterogeneity the $O E C D$ dummy is used instead.

${ }^{13}$ In a sensitivity analysis, yearly dummies will be used instead of decades to account for the time-effects. As credit boom spells do not overlap all the time over the panel of individuals and period analysed, the use of year-dummies will be undermined by the lack of (regressors) variability in some years and the consequent loss of observations. A way to overcome this problem is using decade dummies to account for time-effects. As we have more spells/observations within each decade, the variability of the regressors is not an issue and we can estimate the model without losing observations.
} 
Table 2 The length of credit booms' outcomes

\begin{tabular}{|c|c|c|c|c|c|c|c|}
\hline & (1) & (2) & (3) & (4) & (5) & (6) & (7) \\
\hline$p$ & $\begin{array}{l}1.455^{+, \mathrm{d}} \\
(0.070)\end{array}$ & $\begin{array}{l}1.712^{+, \mathrm{d}} \\
(0.079)\end{array}$ & $\begin{array}{l}1.841^{+, \mathrm{d}} \\
(0.092)\end{array}$ & $\begin{array}{l}1.993^{+, c} \\
(0.104)\end{array}$ & $\begin{array}{l}2.079^{+, c} \\
(0.112)\end{array}$ & $\begin{array}{l}1.900^{+, \mathrm{c}} \\
(0.175)\end{array}$ & $\begin{array}{l}2.041^{+, c} \\
(0.135)\end{array}$ \\
\hline$\Delta p$ & & & & & $\begin{array}{l}-0.338 * * * \\
(0.082)\end{array}$ & & \\
\hline$p+\Delta p$ & & & & & $\begin{array}{l}1.741^{+, \mathrm{d}} \\
(0.107)\end{array}$ & & \\
\hline$B a d C B$ & & & & $\begin{array}{l}-0.786^{* * * *} \\
(0.179)\end{array}$ & & & \\
\hline$F D I g r$ & & & $\begin{array}{l}0.028 * * \\
(0.013)\end{array}$ & $\begin{array}{l}0.024 * * \\
(0.012)\end{array}$ & $\begin{array}{l}0.026^{* *} \\
(0.013)\end{array}$ & $\begin{array}{l}0.036 \\
(0.039)\end{array}$ & $\begin{array}{l}0.024 * * \\
(0.012)\end{array}$ \\
\hline$G D P g r$ & & & $\begin{array}{l}-0.082 * * * \\
(0.017)\end{array}$ & $\begin{array}{l}-0.100 * * * \\
(0.016)\end{array}$ & $\begin{array}{l}-0.098 * * * \\
(0.016)\end{array}$ & $\begin{array}{l}-0.127 * * * \\
(0.032)\end{array}$ & $\begin{array}{l}-0.095 \text { *** } \\
(0.021)\end{array}$ \\
\hline$C A \_G D P$ & & & $\begin{array}{l}0.036^{* * *} \\
(0.013)\end{array}$ & $\begin{array}{l}0.043 * * * \\
(0.014)\end{array}$ & $\begin{array}{l}0.045^{* * *} \\
(0.014)\end{array}$ & $\begin{array}{l}0.025 \\
(0.028)\end{array}$ & $\begin{array}{l}0.048^{* * * *} \\
(0.016)\end{array}$ \\
\hline$O E C D$ & & $\begin{array}{l}-0.126 \\
(0.148)\end{array}$ & $\begin{array}{l}-0.196 \\
(0.159)\end{array}$ & $\begin{array}{l}-0.188 \\
(0.158)\end{array}$ & $\begin{array}{l}-0.171 \\
(0.158)\end{array}$ & $\begin{array}{l}-0.099 \\
(0.304)\end{array}$ & $\begin{array}{l}-0.236 \\
(0.186)\end{array}$ \\
\hline $\operatorname{Dec} 80$ & & $\begin{array}{l}-0.302 \\
(0.228)\end{array}$ & $\begin{array}{l}-0.377 \\
(0.252)\end{array}$ & $\begin{array}{l}-0.214 \\
(0.253)\end{array}$ & $\begin{array}{l}-0.224 \\
(0.253)\end{array}$ & $\begin{array}{l}-0.682 \\
(0.524)\end{array}$ & $\begin{array}{l}-0.043 \\
(0.288)\end{array}$ \\
\hline Dec 90 & & $\begin{array}{l}-0.695 * * * \\
(0.188)\end{array}$ & $\begin{array}{l}-0.876^{* * * *} \\
(0.205)\end{array}$ & $\begin{array}{l}-0.727^{* * *} \\
(0.208)\end{array}$ & $\begin{array}{l}-0.739 * * * \\
(0.207)\end{array}$ & $\begin{array}{l}-0.862 * * \\
(0.400)\end{array}$ & $\begin{array}{l}-0.667 * * * \\
(0.247)\end{array}$ \\
\hline $\mathrm{Dec} 00$ & & $\begin{array}{l}-1.338 * * * \\
(0.207)\end{array}$ & $\begin{array}{l}-1.220 * * * \\
(0.223)\end{array}$ & $\begin{array}{l}-1.213 * * * \\
(0.221)\end{array}$ & $\begin{array}{l}-1.263 * * * \\
(0.220)\end{array}$ & $\begin{array}{l}-1.040 * * \\
(0.510)\end{array}$ & $\begin{array}{l}-1.251^{* * *} \\
(0.250)\end{array}$ \\
\hline Dec10 & & $\begin{array}{l}0.897 * * * \\
(0.240)\end{array}$ & $\begin{array}{l}0.904 * * * \\
(0.258)\end{array}$ & $\begin{array}{l}0.986^{* * * *} \\
(0.260)\end{array}$ & $\begin{array}{l}0.990 * * * \\
(0.261)\end{array}$ & $\begin{array}{l}0.185 \\
(0.726)\end{array}$ & $\begin{array}{l}1.136^{* * * *} \\
(0.284)\end{array}$ \\
\hline \#Obs. & 1781 & 1781 & 1638 & 1638 & 1638 & 547 & 1091 \\
\hline \#Spells & 220 & 220 & 200 & 200 & 200 & 52 & 148 \\
\hline $\log L$ & -649.4 & -608.1 & -531.4 & -521.0 & -522.3 & -142.8 & -376.4 \\
\hline SBIC & 1313.7 & 1268.6 & 1136.9 & 1123.4 & 1026.0 & 348.6 & 822.7 \\
\hline
\end{tabular}

Estimations considering Gourinchas et al. (2001) and Barajas et al. (2009) criteria with threshold equal to 1.5. Robust standard errors are reported in parentheses; ***, **, * - statistically significant at $1 \%, 5 \%$ and $10 \%$ level, respectively; + indicates that $p$ is significantly higher than one using a one-sided test with a $5 \%$ significance level; $d, c$, and $i$ indicate decreasing, constant or increasing positive duration dependence, respectively; $\Delta p$ is the estimated difference in the duration dependence parameter between bad and good credit booms; $p+\Delta p$ is the value of the duration dependence parameter for bad credit booms. The Schwartz Bayesian Information Criterion (SBIC) is computed as follows: $S B I C=-2 \log L+k \log N$, where $k$ is the number of regressors and $N$ is the number of observations (spells). Columns 6 and 7 present separate regression results for bad and good credit booms, respectively

before translating into new credits and due to the instability and uncertainty they can generate (Calderón and Kubota 2012). On the contrary, credit booms last longer when the economy is growing faster: a one percentage point increase in GDP growth leads to a decrease of $9.5 \%$ in the hazard of a credit boom ending, i.e. it has a significant negative impact on the likelihood of a credit boom ending 
over time. ${ }^{14}$ Finally, a better current account position $\left(C A \_G D P\right)$ is found to be associated with shorter credit booms. This result can be justified by the fact that an improvement in the current account balance means more cash/liquidity available and less need for further credit, hence, implying shorter credit booms. All these results are in line with our expectations.

To test whether bad credit booms are statistically longer than benign ones, a dummy that takes the value of 1 for those that end up in a banking crisis, and 0 otherwise $(B a d C B)$, is added to the model. The results show that bad credit booms have a lower likelihood of ending, i.e. they are significantly longer than good ones (see column 4). More specifically, bad credit booms have a hazard of ending that is $54.4 \%(=100 *[\exp (-0.786)-1])$ lower than good ones.

Next, allowing for a change in the duration dependence parameter $(\Delta p)$ between good $(p)$ and bad credit boom episodes $(p+\Delta p)$, we observe a significant difference in the duration dependence parameter between them (see column 5): $p$ is statistically lower for credit booms that are followed by a banking crisis. Moreover, good credit booms present constant positive duration dependence while for bad ones it is decreasing. Hence, the likelihood of bad credit booms ending increases over time at a lower rate than good ones. In other words, this provides further evidence that the former has a higher propensity to last longer than the latter. Finally, separate regressions for those different episodes confirm this trend (see columns 6 and 7). Overall, these findings are in line with what we observe in Table 1 and provide the lacking statistical evidence for what has been argued (but not proved yet) in the literature: credit booms that end up or are followed by banking crises are indeed statistically longer than those that land softly. ${ }^{15}$

\subsection{Sensitivity Analysis}

In this sub-section, we provide a sensitivity analysis where specification 4 in Table 2 is used as baseline. The results of this analysis are reported in Table 3 .

The size of the credit boom, as it builds up over time, is another issue that might be linked to its duration. To control for this potential link, the lag of the ratio of credit to GDP (Credit_GDP) is added to the model as a proxy for the magnitude of the boom. ${ }^{16}$ The results show that the size is negatively associated to duration, but the effect is only marginally significant (see column 1 in Table 3 ). At the same time, this effect seems to be interrelated with the effect of FDIgr, which becomes statistically insignificant; the other results remain unchanged though. As noticed above, capital inflows may fuel new

\footnotetext{
${ }^{14}$ According to Allison (2014), this estimate is obtained as $100 *[\exp (b)-1]$. This corresponds to the percentage change in the hazard for a unit increase in the respective regressor. For the purpose of interpretation, $b$ was chosen to be the estimated coefficient on GDPgr in regression $4(b=-0.1)$.

${ }^{15}$ In the Annex are provided some robustness checks where different thresholds for the identification of credit booms (1.75 and 2.0) are considered (see Table 5.); a different definition and detrending technique are also used (see Table 6). In Table 6 we compare the results from regressions considering credit booms identified using the Hodrick-Prescott filter and Hamilton (2018) filter (both with threshold equal to 1.5 but without using the $20 \%$ growth rate of $L / y$ as an additional marker of credit booms). The results reported in these additional tables corroborate all the findings presented above.

${ }^{16}$ Note that in this duration analysis we only use the spells of credit boom, hence the magnitude of this ratio can work as a good proxy for the size of the boom.
} 


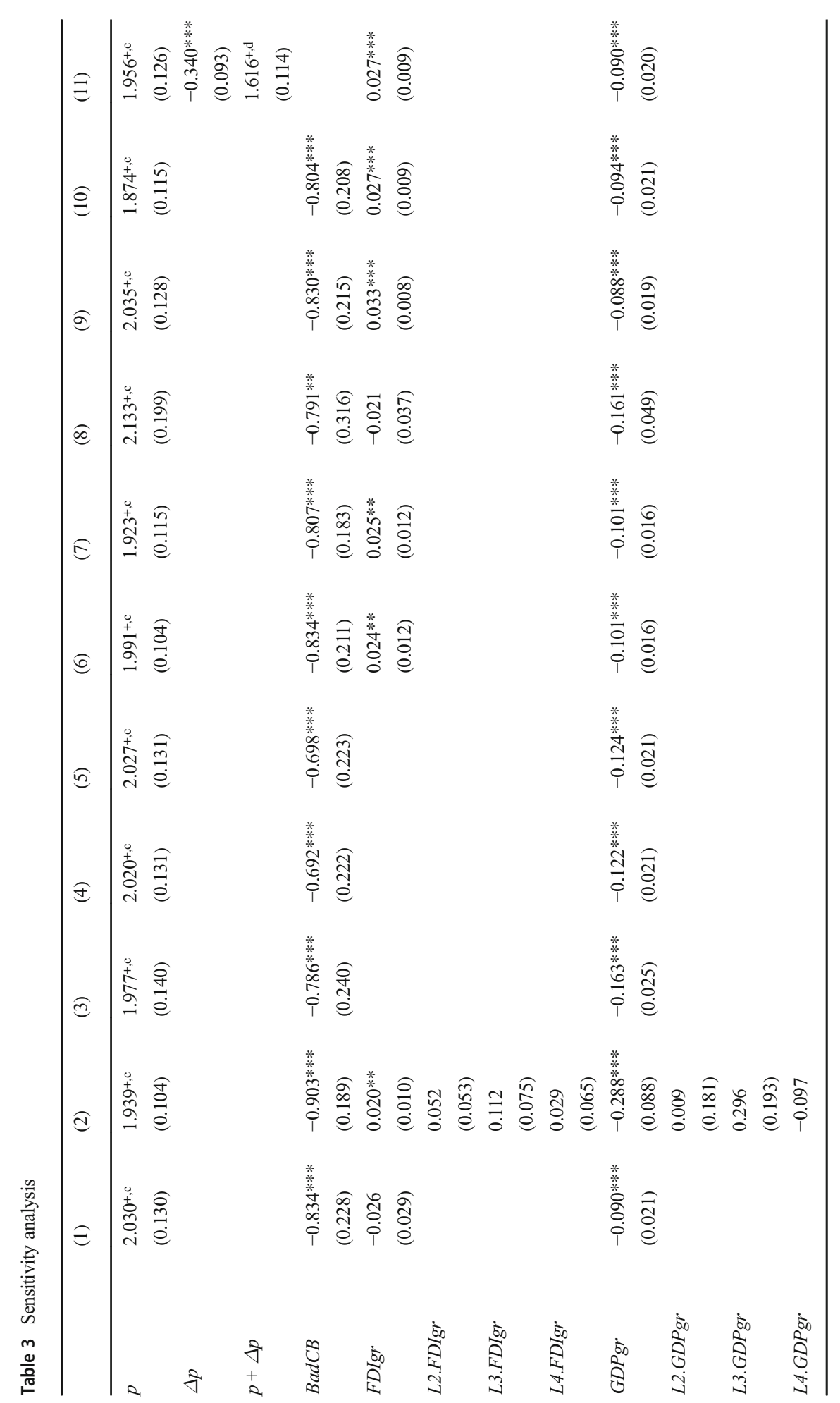




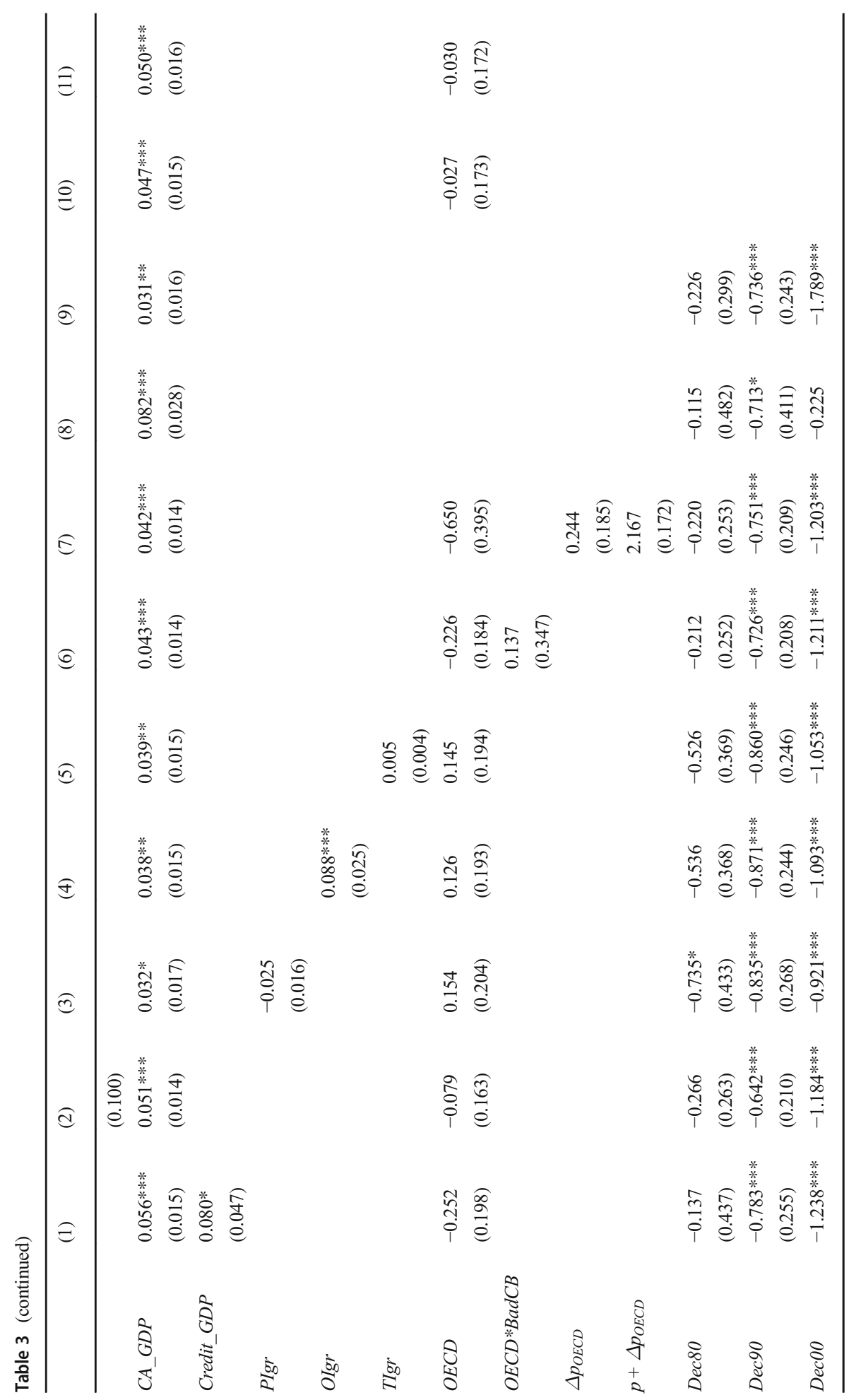




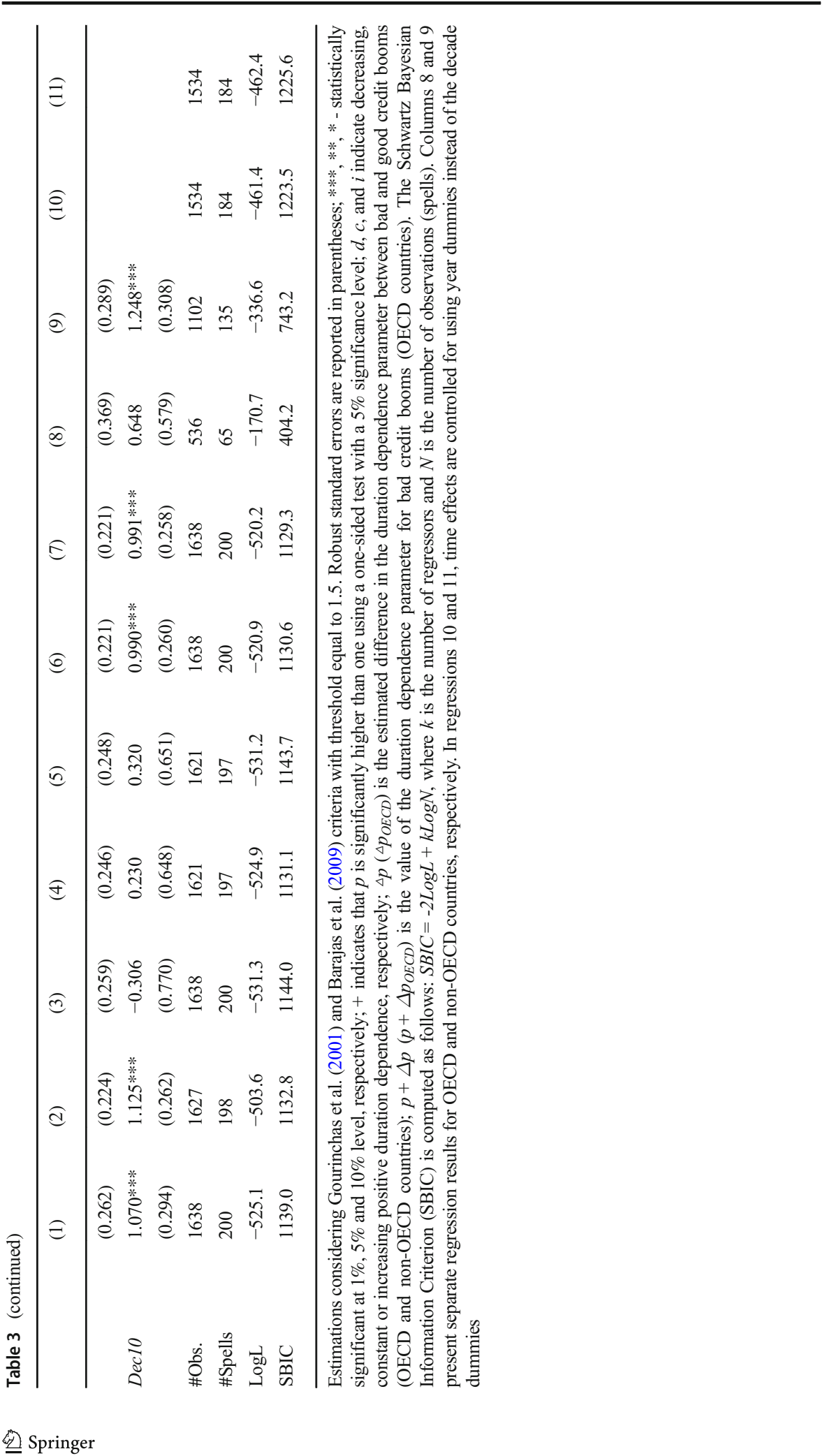


credits, hence FDIgr might be enough to account for the size effect. Moreover, Credit_GDP is used to identify credit booms and its duration, so for that reason it might technically be adding some bias to the analysis.

Next, we control for further lags of FDIgr and GDPgr to capture any additional missing past information. The results strongly suggest that one lag of those variables is enough to capture their effect on the duration of credit booms. In regressions 3-5, FDIgr is replaced by the growth rate of portfolio investment inflows $(\mathrm{PIgr})$, other investment inflows $(\mathrm{OIg} r)$ and total inflows $(\mathrm{TIgr})$, respectively. The results show that $O I g r$ also affects the duration of credit booms in the same direction as FDIgr. This finding is consistent with the idea that countries with a lower equity-debt ratio in foreign flows tend to experience lending booms more frequently (Calderon and Kubota 2012). As that lower ratio seems to be somehow driven by a higher amount of cross-border banking flows, an acceleration in OI inflows will make credit booms more frequent (Calderon and Kubota 2012) and, consequently, shorter.

Even though the mean duration of credit booms has not proven to be significantly different between OECD and non-OECD countries, it would be interesting to analyse whether differences arise regarding bad credit booms. To control for this effect, we start by interacting $B a d C B$ with $O E C D$ (see regression 6). The results are in line with what we have found for all credit booms. Moreover, no differences are found in the duration dependence dynamics either (regression 7). Even when we split the sample into OECD (regression 8) and non-OECD countries (regression 9) results show identical duration dependence dynamics and a higher propensity for bad credit booms lasting longer than good ones in both groups.

As a final exercise, yearly dummies are used instead of decades to account for the timeeffects (see columns 10 and 11). As expected, for the reasons mentioned above, the number of observations and events decreases. Nevertheless, our findings and conclusions remain qualitatively and quantitatively unchanged.

\subsection{Build-Up and Unwinding Phases of Credit Booms}

In this sub-section we dig deeper in the analysis of credit boom dynamics by assessing whether their build-up and unwinding phases are longer when credit expansions end up in a banking crisis. ${ }^{17}$ This analysis will help us to understand where the dynamics for longer and harmful credit booms is generated: sooner in the process, i.e. in the build-up phase, or later when credit booms unwind.

The results reported in Table 4 show that bad credit booms exhibit longer buildups and longer unwindings when compared to other credit expansions (see columns 2 and 5). Allowing for a change in the duration dependence parameter (columns 3 and 6), we reach a similar conclusion: in each phase, the likelihood of termination

\footnotetext{
${ }^{17}$ Build-ups are defined as the initial phase of the credit boom. They correspond to the period between the start of the credit boom and the beginning of the unwinding phase. They last, on average, 5.7 quarters; the average is higher for bad ( 7.5 quarters) than for good credit booms (5.0 quarters). The unwinding phase starts when credit-to-GDP growth becomes negative (and stays negative for at least two quarters) while the credit boom is still alive; when this does not happen during the credit boom phase, the unwinding is considered to be the last quarter of the boom. Unwindings last, on average, 2.4 quarters; the average is also higher for bad (3.2 quarters) than for good credit booms (2.1 quarters).
} 
Table 4 The duration of the build-up and unwinding of credit booms

\begin{tabular}{|c|c|c|c|c|c|c|c|}
\hline & \multicolumn{3}{|l|}{ Build-up } & \multicolumn{4}{|c|}{ Unwinding } \\
\hline & (1) & (2) & (3) & (4) & (5) & (6) & (7) \\
\hline$p$ & $\begin{array}{l}1.292^{+, \mathrm{d}} \\
(0.088)\end{array}$ & $\begin{array}{l}1.334^{+, \mathrm{d}} \\
(0.090)\end{array}$ & $\begin{array}{l}1.367^{+, \mathrm{d}} \\
(0.096)\end{array}$ & $\begin{array}{l}1.341^{+, \mathrm{d}} \\
(0.137)\end{array}$ & $\begin{array}{l}1.378^{+, \mathrm{d}} \\
(0.139)\end{array}$ & $\begin{array}{l}1.508^{+, \mathrm{d}} \\
(0.156)\end{array}$ & $\begin{array}{l}1.607^{+, d} \\
(0.158)\end{array}$ \\
\hline$\Delta p$ & & & $\begin{array}{l}-0.169 * \\
(0.095)\end{array}$ & & & $\begin{array}{l}-0.367 * * \\
(0.182)\end{array}$ & $\begin{array}{l}-0.468^{* *} \\
(0.194)\end{array}$ \\
\hline$p+\Delta p$ & & & $\begin{array}{l}1.197 \\
(0.128)\end{array}$ & & & $\begin{array}{l}1.141 \\
(0.177)\end{array}$ & $\begin{array}{l}1.139 \\
(0.187)\end{array}$ \\
\hline $\operatorname{Bad} C B$ & & $\begin{array}{l}-0.514 * * * \\
(0.169)\end{array}$ & & & $\begin{array}{l}-0.444 * * \\
(0.188)\end{array}$ & & \\
\hline Buildup & & & & & & & $\begin{array}{l}0.023 \\
(0.016)\end{array}$ \\
\hline$F D I g r$ & $\begin{array}{l}0.006 \\
(0.005)\end{array}$ & $\begin{array}{l}0.006 \\
(0.005)\end{array}$ & $\begin{array}{l}0.005 \\
(0.005)\end{array}$ & $\begin{array}{l}0.024 * * \\
(0.012)\end{array}$ & $\begin{array}{l}0.020^{*} \\
(0.012)\end{array}$ & $\begin{array}{l}0.022 * \\
(0.012)\end{array}$ & $\begin{array}{l}0.026^{*} \\
(0.015)\end{array}$ \\
\hline$G D P g r$ & $\begin{array}{l}-0.082 * * * \\
(0.019)\end{array}$ & $\begin{array}{l}-0.089^{* * *} \\
(0.019)\end{array}$ & $\begin{array}{l}-0.083 * * * \\
(0.019)\end{array}$ & $\begin{array}{l}0.029 \\
(0.021)\end{array}$ & $\begin{array}{l}0.013 \\
(0.022)\end{array}$ & $\begin{array}{l}0.017 \\
(0.022)\end{array}$ & $\begin{array}{l}0.018 \\
(0.023)\end{array}$ \\
\hline$C A \_G D P$ & $\begin{array}{l}0.013 \\
(0.014)\end{array}$ & $\begin{array}{l}0.014 \\
(0.014)\end{array}$ & $\begin{array}{l}0.014 \\
(0.014)\end{array}$ & $\begin{array}{l}0.032 * * \\
(0.014)\end{array}$ & $\begin{array}{l}0.043 * * * \\
(0.014)\end{array}$ & $\begin{array}{l}0.042 * * * \\
(0.014)\end{array}$ & $\begin{array}{l}0.046^{* * *} \\
(0.015)\end{array}$ \\
\hline$O E C D$ & $\begin{array}{l}-0.034 \\
(0.164)\end{array}$ & $\begin{array}{l}0.001 \\
(0.165)\end{array}$ & $\begin{array}{l}-0.009 \\
(0.165)\end{array}$ & $\begin{array}{l}-0.475^{* * *} \\
(0.166)\end{array}$ & $\begin{array}{l}-0.510^{* * *} \\
(0.170)\end{array}$ & $\begin{array}{l}-0.508^{* * *} \\
(0.168)\end{array}$ & $\begin{array}{l}-0.518^{* * *} \\
(0.173)\end{array}$ \\
\hline $\operatorname{Dec} 80$ & $\begin{array}{l}0.113 \\
(0.292)\end{array}$ & $\begin{array}{l}0.217 \\
(0.294)\end{array}$ & $\begin{array}{l}0.182 \\
(0.295)\end{array}$ & $\begin{array}{l}-0.312 \\
(0.264)\end{array}$ & $\begin{array}{l}-0.256 \\
(0.264)\end{array}$ & $\begin{array}{l}-0.279 \\
(0.261)\end{array}$ & $\begin{array}{l}-0.216 \\
(0.265)\end{array}$ \\
\hline $\operatorname{Dec} 90$ & $\begin{array}{l}-0.201 \\
(0.250)\end{array}$ & $\begin{array}{l}-0.041 \\
(0.256)\end{array}$ & $\begin{array}{l}-0.097 \\
(0.258)\end{array}$ & $\begin{array}{l}-0.604 * * * \\
(0.205)\end{array}$ & $\begin{array}{l}-0.546^{* * *} \\
(0.207)\end{array}$ & $\begin{array}{l}-0.583 * * * \\
(0.205)\end{array}$ & $\begin{array}{l}-0.626^{* * *} \\
(0.208)\end{array}$ \\
\hline $\operatorname{Dec} 00$ & $\begin{array}{l}-0.275 \\
(0.257)\end{array}$ & $\begin{array}{l}-0.190 \\
(0.260)\end{array}$ & $\begin{array}{l}-0.242 \\
(0.258)\end{array}$ & $\begin{array}{l}-0.549^{\text {**** }} \\
(0.211)\end{array}$ & $\begin{array}{l}-0.577 * * * \\
(0.213)\end{array}$ & $\begin{array}{l}-0.603 * * * \\
(0.216)\end{array}$ & $\begin{array}{l}-0.672^{* * *} \\
(0.222)\end{array}$ \\
\hline Dec10 & $\begin{array}{l}1.229 * * * \\
(0.289)\end{array}$ & $\begin{array}{l}1.304 * * * \\
(0.291)\end{array}$ & $\begin{array}{l}1.283 * * * \\
(0.293)\end{array}$ & $\begin{array}{l}0.394 \\
(0.270)\end{array}$ & $\begin{array}{l}0.309 \\
(0.273)\end{array}$ & $\begin{array}{l}0.355 \\
(0.271)\end{array}$ & $\begin{array}{l}0.262 \\
(0.306)\end{array}$ \\
\hline \#Obs. & 1167 & 1167 & 1167 & 463 & 463 & 463 & 452 \\
\hline \#Spells & 198 & 198 & 198 & 193 & 193 & 193 & 182 \\
\hline $\log L$ & -501.1 & -496.3 & -499.5 & -298.4 & -295.4 & -296.3 & -286.2 \\
\hline SBIC & 1072.9 & 1070.2 & 1076.6 & 658.2 & 658.4 & 660.1 & 645.7 \\
\hline
\end{tabular}

See Table 2. Build-up phases correspond to the period between the start of the credit boom and the beginning of the unwinding phase. Unwinding phases of the credit booms start when credit-to-GDP growth becomes negative (and stays negative for at least two quarters); when this does not happen during the credit boom phase, the unwinding is considered to be the last quarter of the boom. Mean duration (standard-deviation) of build-ups is 5.7 (5.4) quarters; Mean duration (standard-deviation) of unwindings is 2.4 (1.9) quarters

increases over time at a lower rate for bad credit booms than for good ones. Moreover, the upward and downward phases of good credit booms exhibit positive duration dependence, while no duration dependence is observed in any phase related to bad credit expansions. All this additional evidence is corroborating the conclusion above that the duration process of credit booms that end up or are followed by banking crises are fundamentally different than those that end softly. As differences in the duration dynamics between good and bad credit booms are detected in the build-up phase of credit booms, a closer monitorization of the build-up of credit and their duration by policymakers is fundamental for the timing of the implementation of policy measures aimed at mitigating their potential nefarious consequences. 
There are two additional results in Table 4 that are worth to mention. First, the evidence in favour of duration dependence is stronger for unwindings than build-ups. This implies that unwindings are shorter than build-ups. ${ }^{18}$ Unwindings are the fade out process of credit booms. Hence, it is not surprising that the likelihood of these events ending increases over time at a faster pace. Their length is also shortened by capital inflows growth and sounder external accounts. Build-ups, however, are more significantly associated with the expansion of output. As this is an important driver of the duration of credit booms, it is also reasonable that its effects are stronger in the initial phase of the credit expansion, contributing for their build-up.

Second, as there might be a link between build-ups and unwindings of credit booms, an additional regressor was included in the last column of Table 4: the duration of the build-up that preceded the unwinding (Buildup). The results show that the unwinding dynamics is not influenced by the length of the previous buildup. Hence, the unwinding phases are mainly driven by the (positive) duration dependence dynamics and are more prone to last longer in the group of more developed (OECD) countries.

\section{Conclusions}

Several papers in the literature have stated that credit expansions that end up in banking crises are usually longer than those that do not. However, proper statistical evidence for this is scarce. This paper employs a discrete-time duration model to assess the relationship between the length of credit booms and their outcome using a quarterly dataset covering 67 countries from 1975q1 to 2016 q.

The empirical analysis shows that harmful credit expansions are indeed more prone to last longer than those that land softly. In particular, the time dynamics between them is found to be different: while bad credit booms present decreasing duration dependence, good ones run to its end (over time) at a faster pace. This provides the missing statistical evidence for what is argued in the literature. Moreover, we also show that this dynamic begins when credit booms build-up and continues when they unwind. Both the expansion and the termination phases of harmful credit surges are longer than for innocuous ones. The results also provide evidence that, in general, the resolution phases are shorter than the build-ups.

This paper shows that duration can be seen as an early warning instrument to evaluate the benign or malignant nature of credit booms. Nevertheless, the length of a credit boom alone is not enough to suggest the nature of a credit expansion. It is a symptom that depends on other symptoms to get a trustworthy diagnostic. For example, we observe that capital inflows, economic growth and the external accounts stance help to explain the length of credit booms. Still, their duration can work as a reliable wake-up call, since it has been the most consistent distinctive characteristic highlighted in the literature.

\footnotetext{
${ }^{18}$ In fact, in our sample we observe that the mean duration of build-ups is 5.7 quarters while for unwindings it is only 2.4 quarters. The duration analysis confirms this dynamic for shorter unwindings.
} 


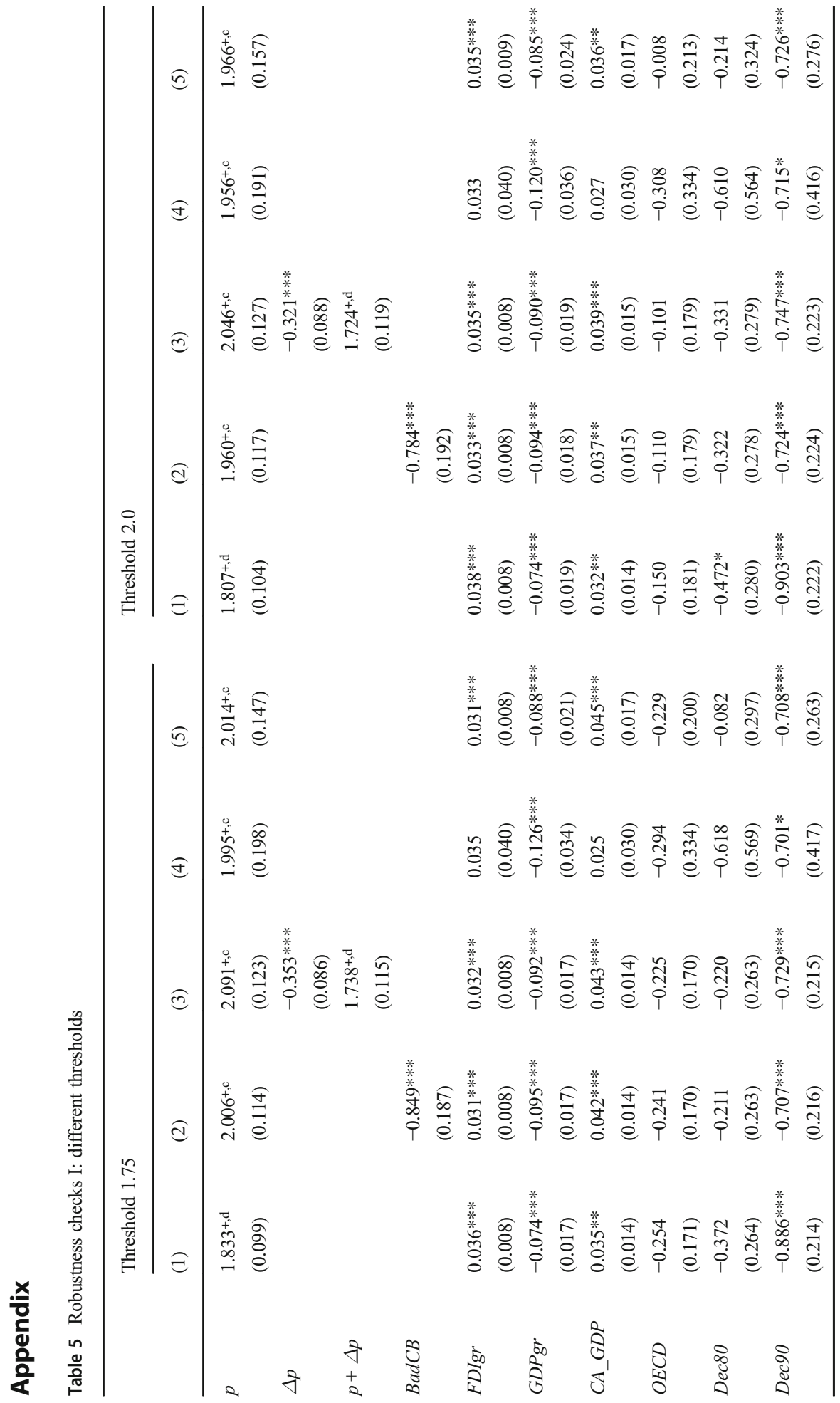




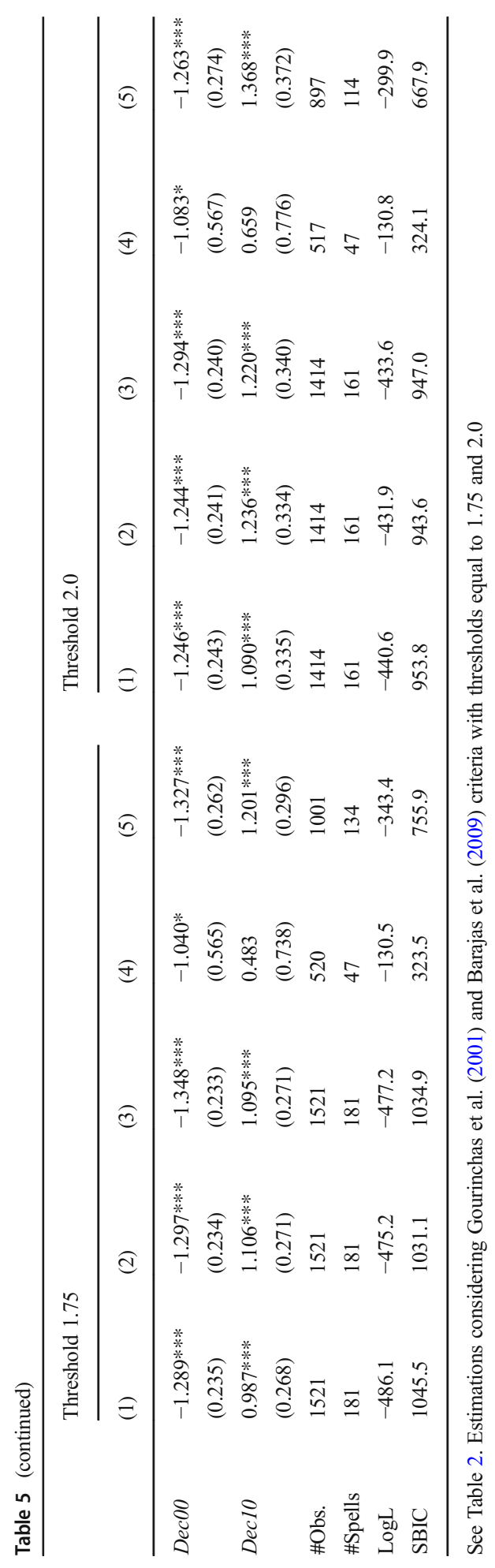




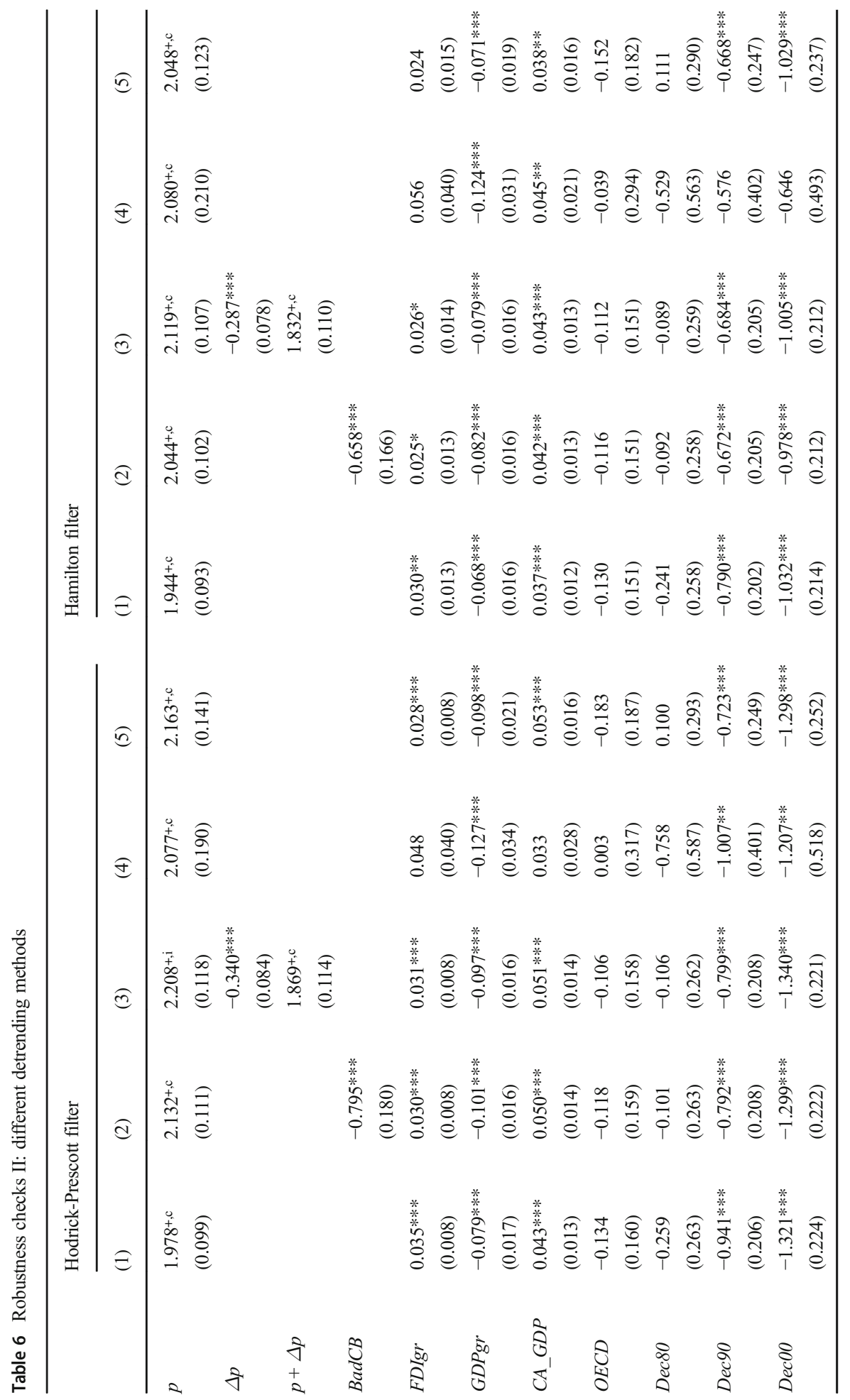




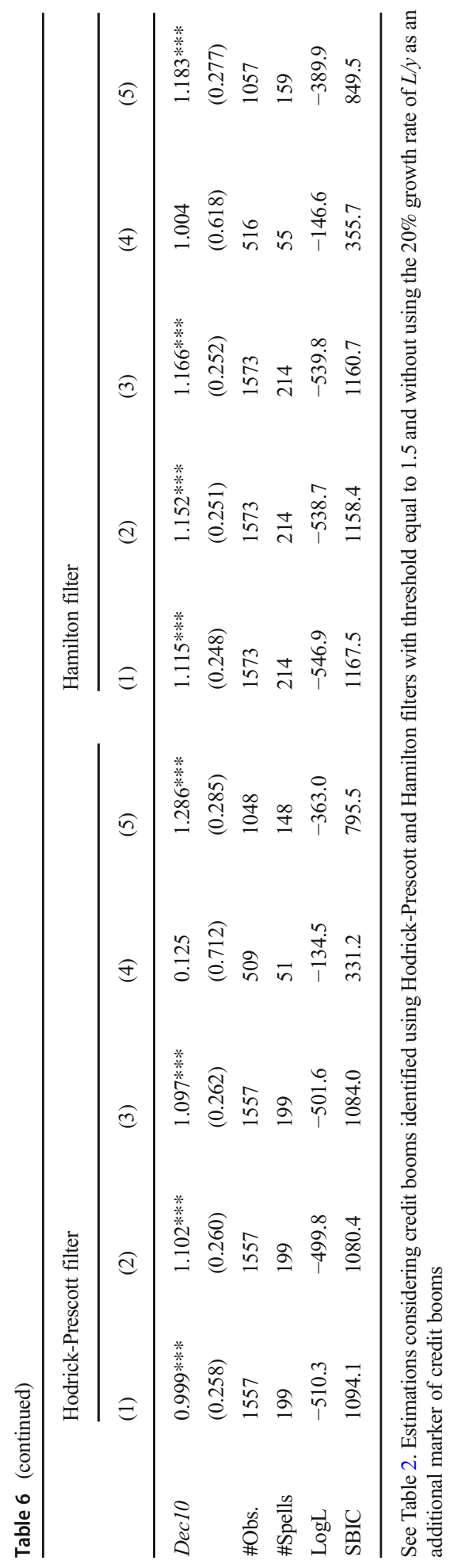


A closer monitorization of the banking system when a boom exceeds their average duration (eight quarters in our sample) is important as credit booms are more likely to unfold in a systemic banking crisis when they surpass that "age". Nevertheless, as differences in the duration dynamics between good and bad credit booms are detected earlier, in their build-up phase - as our results show that monitorization is advisable to take place sooner, as a precautionary measure. We would suggest the average duration of the build-up of credit booms (i.e. around one year and a half) as a good rule-of thumb for policymakers to start monitoring episodes of credit booms. Nevertheless, we think that the use of invasive policy measures that interfere directly with the economy and the financial sector requires additional economic information. The relevant results provided by this study suggest that early warning systems should not be built exclusively around economic variables, but also include the duration aspect of credit expansions.

As a final word of advice, we claim that the use of invasive policy measures that interfere directly with the economy and the financial sector should require additional economic information. The strong results provided by this study suggest that early warning systems should not be built exclusively around economic variables, but also include the duration aspect of credit expansions.

Acknowledgements The authors would like to thank three anonymous referees for their very insightful comments and suggestions.

Open Access This article is distributed under the terms of the Creative Commons Attribution 4.0 International License (http://creativecommons.org/licenses/by/4.0/), which permits unrestricted use, distribution, and reproduction in any medium, provided you give appropriate credit to the original author(s) and the source, provide a link to the Creative Commons license, and indicate if changes were made.

\section{References}

Agnello L, Castro V, Sousa R (2013) What determines the duration of a fiscal consolidation program? J Int Money Financ 37:113-134

Agnello L, Castro V, Sousa R (2015) Booms, busts and normal times in the housing market. J Bus Econ Stat 33(1):25-45

Agnello L, Castro V, Sousa R (2018) The legacy and the tyranny of time: exit and re-entry of sovereigns to international capital markets. J Money Credit Bank forthcoming

Allison P (1982) Discrete-time methods for the analysis of event histories. Sociol Methodol 13:61-98

Allison P (2014) Quantitative applications in the social sciences: event history and survival analysis. SAGE Publications, Thousand Oaks

Arena, M., Bouza, S., Dabla-Norris, M. E., Gerling, M. K., and Njie, L. (2015). Credit booms and macroeconomic dynamics: stylized facts and lessons for low-income countries (IMF working paper 15/ 11). International Monetary Fund

Avdjiev, S., Binder, S., and Sousa, R., 2018. External debt composition and domestic credit cycles. European Stability Mechanism, Working-paper series, 28

Barajas, A., Dell'Ariccia, G., and Levchenko, A., 2009. Credit booms: the good, the bad, and the ugly. Unpublished manuscript, International Monetary Fund (Washington, DC)

Baron M, Xiong W (2017) Credit Expansion and Neglected Crash Risk. Q J Econ 132(2):713-764

Boissay F, Collard F, Smets F (2016) Booms and banking crises. J Polit Econ 124(2):489-538 
Calderón C, Kubota M (2012) Gross inflows gone wild: gross capital inflows, credit booms and crises. World Bank policy research working paper no. 6270

Castro V (2010) The duration of economic expansions and recessions: more than duration dependence. J Macroecon 32:347-365

Castro, V., and Kubota, M., 2013. Duration dependence and change-points in the likelihood of credit booms ending. Policy research working paper 6475, The World Bank

Castro V, Martins R (2013) Is there duration dependence in Portuguese local governments' tenure? Eur J Polit Econ 31:26-39

Castro V, Martins R (2018) Why are credit booms sometimes sweet and sometimes sour? University of Coimbra, CeBER WP no. 14

Castro V, Martins R (2019) The political and institutional determinants of credit booms. Oxf Bull Econ Stat 81(5):1144-1178

Claessens S, Ayhan Kose M, Terrones ME (2012) How do business and financial cycles interact? J Int Econ 87(1):178-190

Dell'Ariccia G, Igan D, Laeven L, Tong H (2016) Credit booms and macrofinancial stability. Econ Policy 31(86):299-355

Elekdag S, Wu Y (2013) Rapid credit growth in emerging markets: boon or boom-bust? Emerg Mark Financ Trade 49(5):45-62

Gourinchas P-O, Valdes R, Landerretche O (2001) Lending booms: Latin America and the world. Economia 1(2):47-99

Gourinchas P-O, Obstfeld M (2012) Stories of the twentieth century for the twenty-first. Am Econ J Macroecon 4(1):226-265

Hamilton J (2018) Why you should never use the Hodrick-Prescott filter. Rev Econ Stat 100(5):831-843

Jordà Ò, Schularick M, Taylor A (2011) Financial crises, credit booms, and external imbalances: 140 years of lessons. IMF Economic Review 59(2):340-378

Jordà Ò, Schularick M, Taylor A (2016) Sovereigns versus banks: credit, crises, and consequences. J Eur Econ Assoc 14(1):45-79

Laeven L, Valencia F (2008) Systemic banking crises: a new database. International Monetary Fund working paper $08 / 224$

Laeven L, Valencia F (2010) Resolution of banking crises: the good, the bad, and the ugly. International Monetary Fund working paper 10/146

Laeven L, Valencia F (2012) Systemic banking crises database: an update. International Monetary Fund working paper $12 / 163$

Mendoza E, Terrones M (2008) An anatomy of credit booms: evidence from macro aggregates and micro data. NBER working paper no. 14049

Mendoza E, Terrones M (2012) An anatomy of credit booms and their demise. NBER working paper no. 18379

Meng C, Gonzalez RL (2017) Credit booms in developing countries: are they different from those in advanced and emerging market countries? Open Econ Rev 28(3):547-579

Prentice R, Gloeckler L (1978) Regression analysis of grouped survival data with application to the breast cancer data. Biometrics 34:57-67

Amri PD, R., Greg M., Willett, T. D. (2016) Capital surges and credit booms: how tight is the relationship? Open Econ Rev 27(4):637-670

Schularick M, Taylor A (2012) Credit booms gone bust: monetary policy, leverage cycles, and financial crises, 1870-2008. Am Econ Rev 102(2):1029-1061

Publisher's Note Springer Nature remains neutral with regard to jurisdictional claims in published maps and institutional affiliations. 